\title{
Teaching Grammar Through Data-Driven Learning (DDL) Approach
}

\author{
Sidik Indra Nugraha, Fauzi Miftakh, Kelik Wachyudi \\ Universitas Singaperbangsa Karawang, Indonesia \\ sidik.indranugraha@staff.unsika.ac.id \\ miftakh.fauzi@yahoo.co.id \\ kelik.wachyudi@staff.unsika.ac.id
}

\begin{abstract}
Although English has been taught as a compulsory subject from elementary to college level, many students consider English a challenging one especially when dealing with grammar. This paper reported an implementation of teaching grammar to students specialized in midwifery by integrating a Data-Driven Approach (DDL) into grammar teaching. DDL approach has gained popularity in English Language Teaching (ELT) in the last decade considering its benefits to empowering students to learn grammar inductively, and encourage students to be active. This research was qualitative at large and conducted in an EFL class of midwifery major at a state university in Karawang regency, West Java. Thirty students participated in this research. It lasted two months, in which students prepared and worked on specific grammar items, for example, conjunction, countable and uncountable nouns, and possessive pronoun, for about ninety minutes in the class hour. Student responses were drawn to reveal their attitudes and responses towards the implementation of the DDL approach in teaching grammar. The results showed the way the DDL approach was implemented in teaching grammar through four stages of teaching procedures, as proposed by Oghigian and Chujo (2010), including hypothesis formation through inductive DDL tasks, explicit explanation from the teacher to conform or to correct these hypotheses, hypotheses testing through follow-up exercises (homework) and teacher feedback on homework, and production through followup exercises (in class) and teacher feedback on homework. In addition, most students responded positively towards the implementation of DDL in learning grammar. The research concluded that DDL approach can be an effective learning approach to teaching and learning grammar for its incentives to encourage students to be active language learners.
\end{abstract}

Keywords: Data-Driven Learning, teaching grammar, active learning.

\section{INTRODUCTION}

English teaching and learning should always bring innovation especially in this digital era. Undoubtedly, the use of information and communication technologies has become part of teaching and learning in the classroom. In teaching and learning English, the use of computer-based tools has been developed over the last decades and it has a great influence to the learning process both by teacher and students.

Corpus linguistics is one of the methods and sources used by learners of English. Corpus linguistics is a systematic analysis of the actual (real) production of language (either spoken or written) as opposed to intuition. The productions of language can be taken from various authentic sources and fields such as newspaper, magazine, people's speech and conversation and etc. Corpus linguistics has widely contributed in deepening knowledge of existing language items including distinguishing close synonyms, listing the most frequent words, detecting patterns of usage etc. (Gabrielatos, 2005; Leech, 1997).

The use of corpus linguistics in language learning is called Data-Driven Learning (DDL) (Gabrielatos, 2005; Gavioli, 2005; Hadley (2002). In addition, Johns (1991) defines DDL as "the use in the classroom of computergenerated concordances to get students to explore regularities of patterning in the target language, and the development of activities and exercises based on concordance output."

Furthermore, in recent years, many scholars were stimulated to conduct studies on corpus linguistics especially Data-Driven Learning in English language teaching and learning. The previous studies include studies on Data-driven learning for teaching collocations of prepositions (Yunus \& Awab, 2014; Jafarpour \& Koosha, 2005) and Data-driven learning for teaching English vocabulary (Guan, 2013).

Specifically Yunus \& Awab (2014) and Jafarpour \& Koosha's (2005) studies onData-driven learning for teaching collocations of prepositions found that DDL to be effective in enhancing students' sentence production. In addition, DDL is not related to learners' proficiency levels. Not only do advanced learners but also intermediate and lower proficient ones may get the benefits from DDL. On the other hand, Guan's (2013) study more focused on the teaching and learning English vocabulary in China's EFL Class. He concluded that Corpus-based data-driven teaching and learning provide a large number of instances of real context, and create a learning environment to attract learners ${ }^{\text {ee }}$ attention, be conducive to enhance their memory and help them to use context to obtain the word semantics and summarize the grammatical rules.

This present study also tries to investigate the use of Data-driven learning especially for teaching English grammar to students specialized in midwifery in Indonesia. Different method and setting have provided different results. It is known that in English for specific purposes (ESP), midwifery students need to learn English whose content is determined by the professional needs of the learner Crystal (2003). A similar idea is expressed by Hutchinson and Waters (1987: 19) that "there are some features that can be identified as 'typical' of a 
particular context of use and which, therefore, the learner is more likely to meet in the target situation"

Considering the previous studies above, as far as the researcher knows that this kind of study is still rare to conduct in Indonesia especially in Karawang. Thus, this study attempts to investigate how Data-driven learning approach is implemented in teaching grammar to students specialized in Midwifery is and the responses of the students towards the implementation of DDL in learning grammar are.

\section{METHODS}

This research was qualitative at large and conducted in an EFL class of midwifery major at a state university in Karawang regency, West Java. Thirty students participated in this research. It lasted two months, in which students prepared and worked on specific grammar items, for example, conjunction, countable and uncountable nouns, and possessive pronoun, for about ninety minutes in the class hour. Student responses were drawn to reveal their attitudes and responses towards the implementation of the DDL approach in teaching grammar.

\section{RESULTS AND DISCUSSION}

\subsection{DATA-DRIVEN LEARNING (DDL) COURSE}

The DDL course was implemented through four step classroom activities (developed by Chujo and Oghigian, 2008) as summarized in Table 1. First, by employing the British National Corpus (BNC), students worked on particular grammar items. This was done in groups so that they could share and discuss what they had found on specific grammar rules (hypothesis) they were working on. Second, having worked on groups, the teacher explained and discussed what students had come up with. This was to confirm, clarify, or correct the grammar patterns or students' hypothesis. Third, the teacher had the students worked on additional practice for homework. This was to consolidate their individual retention on the grammar hypothesis they had found. Fourth, students worked some exercises to be completed in the classroom.

Table 1. Four Step DDL course (Chujo and Oghigian, 2008)

$$
\underset{\frac{\mathscr{C}}{\mathbb{8}}}{\text { Description }}
$$

Hypothesis formation through inductive DDL tasks with BNC
corpus

A sample course of DDL was teaching Subject - Verb agreement as shown in Figure 1 and 2 below.

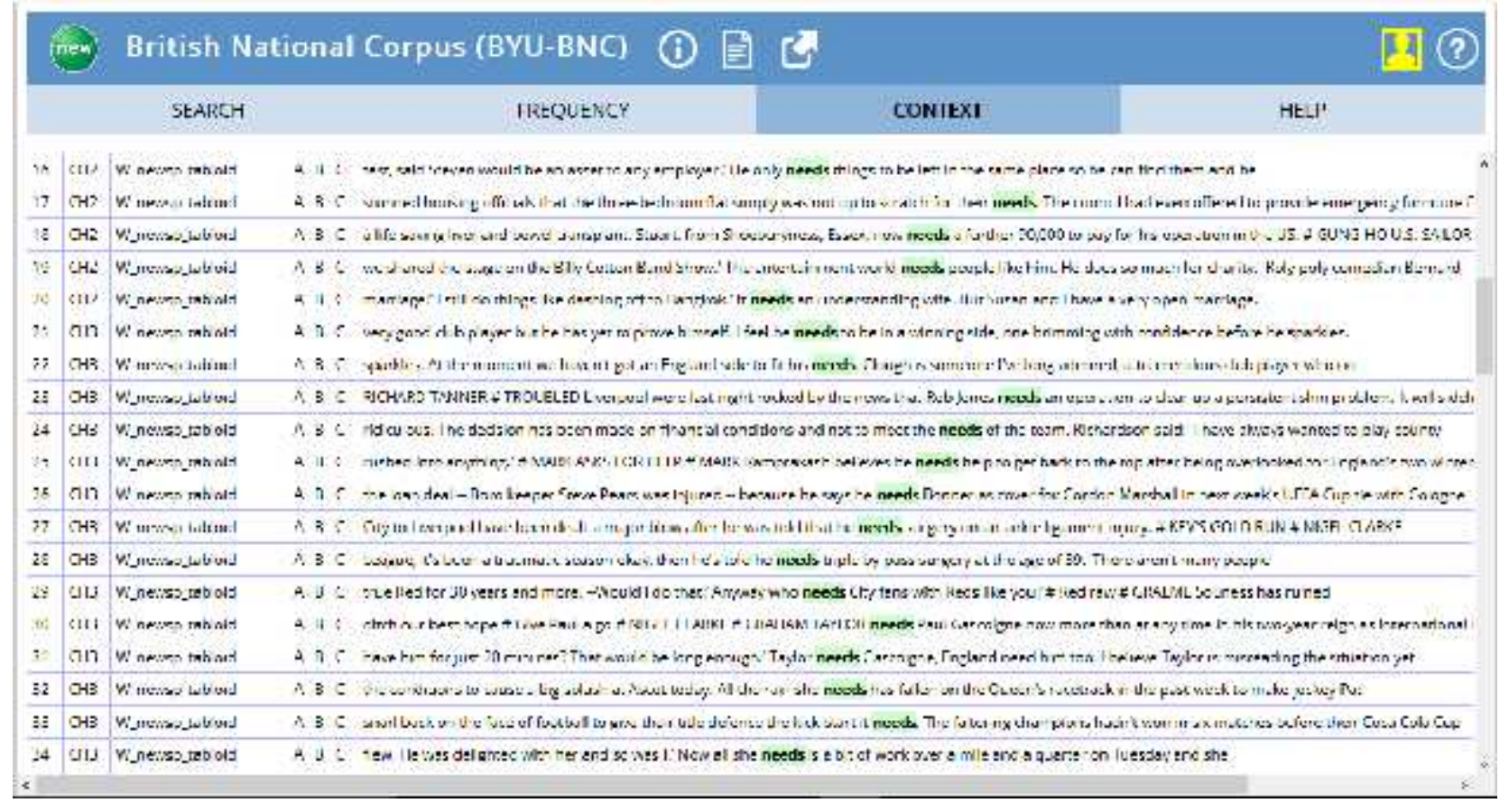

Figure 1: Singular Subject - Verb agreement 
Here the students worked on groups four to find out on the online BNC how this particular point of grammar works. First, the students logged on to the BNC corpus online and begin searching by initially entering a random inflected verb 'needs' to find out how this singular inflected verb agrees its preceding Subject. After typing this keyword, they would find that the inflected verb 'needs' was clearly preceded by singular Subjects like, as can be observed in Figure 1 above, He only needs ... (line 61), The entertainment world needs ... (line 19), All the rain she needs (line 22)etc.

As for the plural Subject - Verb agreement, the students completed similar procedures to that of singular Subject Verb agreement. They typed in the search box a random participle, for example, 'need' to see how this particular type of participle fits its preceding Subject, which is supposed to be plural ones. Then they might have noticed that this particular verb were preceded by plural types of Subject, for example, I need you (line 1), ... they need cutting (line 5), You need close by (line 13) etc., as shown in Figure 2 below.

After students' corpus searching, the next stage was teacher's explanation. This aims to clarify or confirm what the students have discovered. On the third stage, the students completed some practice to consolidate their understanding on Subject - Verb agreement. Since the classroom time was limited, more grammar exercises could be done at home as part of the final stage of the course.

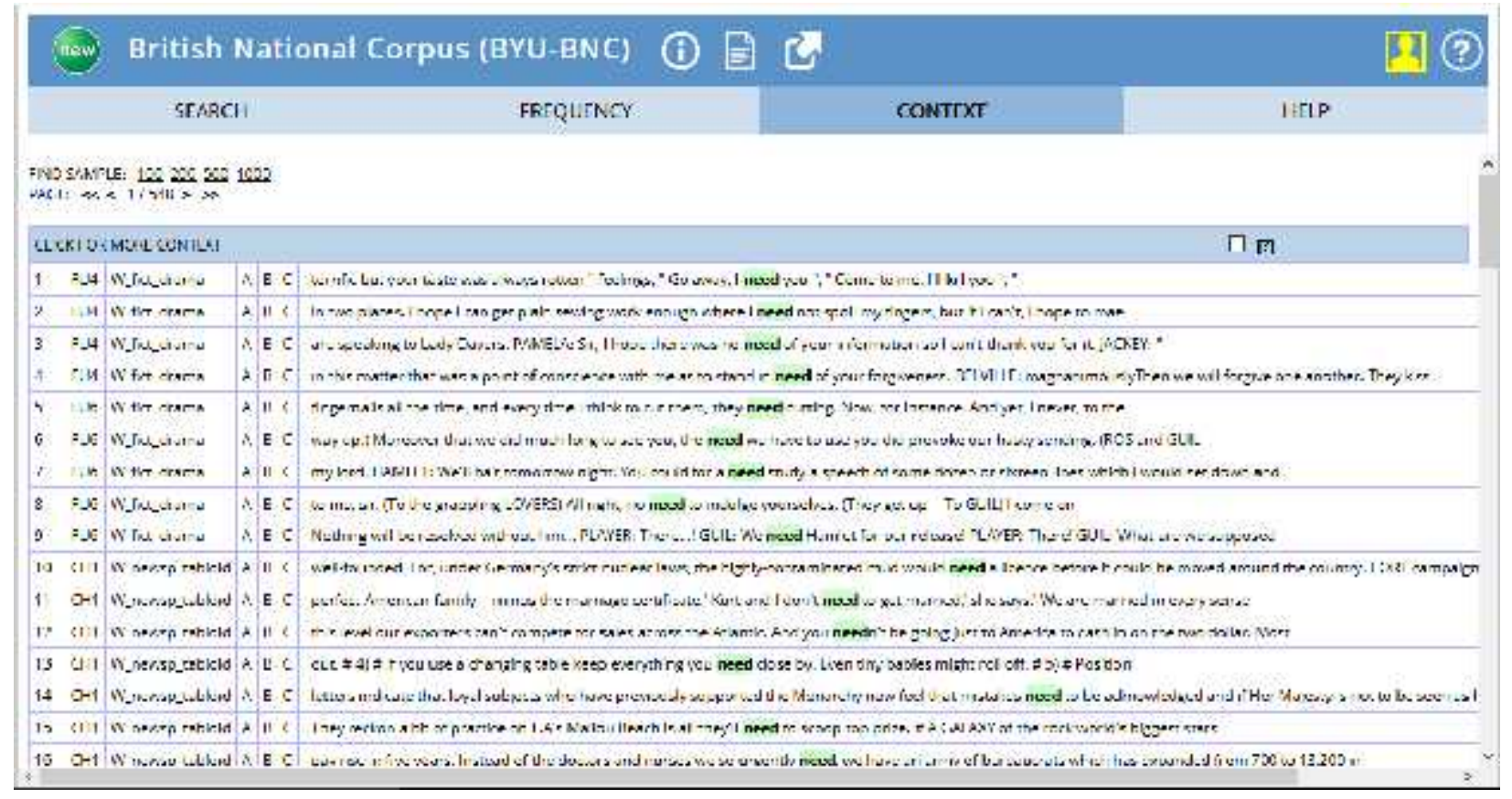

Figure 2: Plural Subject - Verb agreement

Another corpus-based grammar teaching procedure was teaching adjective and adverbs especially when they are constructed from similar base, for example, slow and slowly for the adjective and adverb respectively. This aimed to loot at their functions and the way they are used in the sentence. The corpus including this grammar point is presented in Figure 3 below. As can be observed in Figure 3 below, it is showed that the adjective slow functions to modify the noun, and thus is used typically in noun phrase as indicated in a slow period (line 3), a slow start (line 12), a slow spiral (line 18). In contrast, the adverb slowly functions to modify the verb and thus operates in the sentence as a whole, for example,

\subsection{STUDENTS' RESPONSE ON DDL COURSE}

The participants had no knowledge and previous experience on corpora and its use in learning grammar. After implementing the DDL course, the participants were asked to give their response towards the stages when the DDL course was implemented. Ten item Likert scale was used to rate DDL specified in three rating scales, i.e. strongly agree (rating 3), no strong opinion (rating 2), strongly disagree (rating 3 ). The questionnaire results are presented in Table 1. 
Table 2. Evaluation on Classroom DDL activities

Activities

Evaluation towards the implementation of DDL in learning grammar. The research concluded that DDL approach can be an effective learning approach to teaching and learning grammar for its incentives to encourage students to be active language learners.

\section{REFERENCES}

Crystal, D. (2003). The Cambridge Encyclopedia of the English Language. 2nd ed. Cambridge: Cambridge. University Press.

Gabrielatos, C. (2005). Corpora and language teaching: Just a fling or wedding bells? TESL-EJ, 8(4): 1-35.

Gavioli, L. (2005). Exploring corpora for ESP learning. Amsterdam: John Benjamins.

Guan, X. (2013). A Study on the Application of Data-driven Learning in Vocabulary Teaching and Leaning in China ${ }^{e e}$ s EFL Class. Journal of Language Teaching and Research, 4(1), 105-112.

Hadley, G. (2002). Sensing the Winds of Change: An Introduction to Data-Driven Learning. RELC Journal, 33(2), 99-124.

As can be observed in Table 1, most students responded positively towards the DDL approach. DDL helps me to learn grammar better and Follow up activity is useful appear to be the most noticeably prominent response (87\%). Learners found that DDL course was enjoyable and help them concentrate on the task. Similar results were also found in the other DDL learning activities. It was found that DDL worksheet, grammar explanation, follow up activity, and feedback from teacher were useful. This therefore indicates that learners enjoyed learning grammar through DDL approach and found this approach to be helpful.

\section{STUDENTS' REMARKS ON DDL COURSE}

Furthermore, interview was then administered to seek students' remarks on their experience using the corpora. The analysis revealed themes emerged from the interview as follows:

- This class was different from traditional English lesson.

- I can see the example of grammar use contextually.

- This type of learning is active rather than passive.

- I can see many more example sentences than in a dictionary.

- I had more interest in learning grammar through the task.

\section{CONCLUSION}

The DDL approach was implemented in teaching grammar through four stages of teaching procedures, as proposed by Oghigian and Chujo (2010), including hypothesis formation through inductive DDL tasks, explicit explanation from the teacher to conform or to correct these hypotheses, hypotheses testing through follow-up exercises (homework) and teacher feedback on homework, and production through follow-up exercises (in class) and teacher feedback on homework. In addition, most students responded positively
Hutchinson, T., \& Waters, A. (1987). English for Specific Purposes: A Learning-centred approach. Cambridge: Cambridge University Press.

Jafarpour, A.A., \& Koosha, M. (2005). Data-driven Learning and Teaching collocation of prepositions: The case of Iranian EFL Students. Research on Foreign Languages Journal of Faculty of Letters and Humanities, 200 (49), $1-30$.

Johns, T. (1991). Should you be persuaded: two examples of data driven learning. ELR Journal,4, 1-16.

Leech, G. (1997). Teaching and language corpora: A convergence: In Teaching and language corpora, eds. A. Wichmann, S. Fligelstone, T. McEnery and G. Knowles, 1-23. London: Longman.

Oghigian, K., \& Chujo, K. (2010). An effective way to use corpus exercises to learn grammar basics in English. Language Education in Asia, 1(1), 200-214.

Yunus, K., \& Awab, S. (2014). The impact of Data-driven learning instruction on Malaysian Law Undergraduates' colligational competence. Kajian Malaysia, 32(1), 79109. 